\title{
Isolation of fungal strains for biodegradation and saccharification of microalgal biomass
}

DOI:

10.1016/j.biombioe.2020.105547

\section{Document Version}

Accepted author manuscript

Link to publication record in Manchester Research Explorer

\section{Citation for published version (APA):}

Monjed, M., Robson, G., \& Pittman, J. (2020). Isolation of fungal strains for biodegradation and saccharification of microalgal biomass. Biomass \& Bioenergy, 137, [105547]. https://doi.org/10.1016/j.biombioe.2020.105547

\section{Published in:}

Biomass \& Bioenergy

\section{Citing this paper}

Please note that where the full-text provided on Manchester Research Explorer is the Author Accepted Manuscript or Proof version this may differ from the final Published version. If citing, it is advised that you check and use the publisher's definitive version.

\section{General rights}

Copyright and moral rights for the publications made accessible in the Research Explorer are retained by the authors and/or other copyright owners and it is a condition of accessing publications that users recognise and abide by the legal requirements associated with these rights.

\section{Takedown policy}

If you believe that this document breaches copyright please refer to the University of Manchester's Takedown Procedures [http://man.ac.uk/04Y6Bo] or contact uml.scholarlycommunications@manchester.ac.uk providing relevant details, so we can investigate your claim.

\section{OPEN ACCESS}


1 Isolation of fungal strains for biodegradation and saccharification of microalgal

2 biomass

3

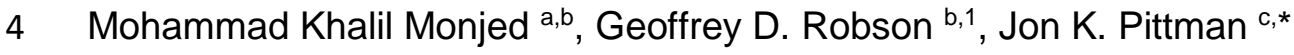

5

6 a Department of Biology, Faculty of Applied Science, Umm Al-Qura University, Makkah,

7 Saudi Arabia

$8{ }^{\mathrm{b}}$ School of Biological Sciences, Faculty of Biology, Medicine and Health, The

9 University of Manchester, Michael Smith Building, Oxford Road, Manchester M13 9PT, 10 UK

$11{ }^{c}$ Department of Earth and Environmental Sciences, School of Natural Sciences,

12 Faculty of Science and Engineering, The University of Manchester, Michael Smith

13 Building, Oxford Road, Manchester M13 9PT, UK

14

$15{ }^{1}$ Deceased

16

$17{ }^{*}$ Corresponding author.

18 Dr Jon Pittman, Department of Earth and Environmental Sciences, The University of

19 Manchester, Michael Smith Building, Oxford Road, Manchester M13 9PT, UK; Tel: +44

20161275 5235; Email: jon.pittman@manchester.ac.uk

21 Orcid id: 0000-0001-7197-1494

22 


\section{Abstract}

24 Products from microalgae have multiple commercial applications including for nutrition, 25 health and fuel uses, but the breakage and release of products from biomass remains a challenge, particularly for microalgal strains with thick cell walls. Fungal strains were isolated due to their ability to degrade microalgal biomass of Parachlorella hussii, Hindakia tetrachotoma and Jaagichlorella luteoviridis that was buried in soil at $25^{\circ} \mathrm{C}$ for 8 weeks. Fungal isolates were identified by sequencing, with the three most ubiquitous strains identified as Fusarium solani, Doratomyces nanus and Actinomucor elegans.

31 Crude enzyme extracts from these strains were used to quantify the saccharification of intact or lipid-extracted Chlorella vulgaris biomass. The $D$. nanus extract gave the highest saccharification efficiency of $57 \%$ from the intact biomass and $76 \%$ from the lipid-extracted biomass, without need for any pre-treatment. Outcomes of this study can improve the design of microbial enzymes to efficiently degrade microalgal biomass for various industrial applications.

37

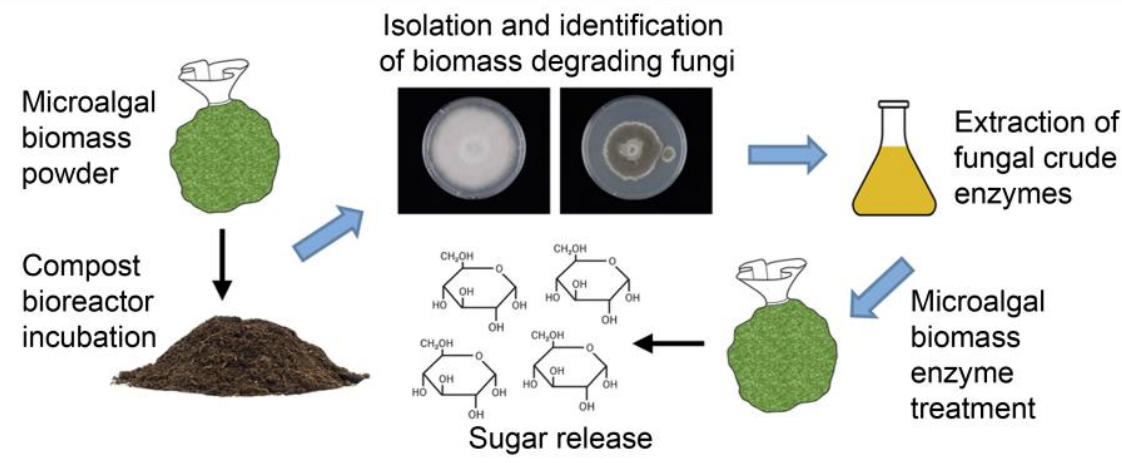

40 Keywords: Chlorella vulgaris; Doratomyces nanus; fungal degradation; microalgal biomass; saccharification. 


\section{Introduction}

The exploitation of microalgae for different industrial applications is being extensively evaluated, and include the uses of microalgal biomass and extracted chemicals and metabolites as pharmaceuticals, cosmetics, human or animal food supplements, and as a feedstock for various forms of biofuel [1-3]. Microalgae are particularly attractive due to their short generation time, high photosynthetic efficiency and ability to be cultivated in a sustainable manner [4]. Various types of biofuel can be generated from microalgal biomass including the conversion of lipids into biodiesel and the use of microalgal derived sugars for fermentation of bioethanol or biobutanol [5-7]. The evaluation of microalgal biomass for biofuel production has generated particular interest, especially because of the potential to shift the dependency away from fossil fuel usage for energy production, and because microalgae can be cultivated on nonarable land and therefore avoid competition with food crop cultivation $[8,9]$. The sustainability and economic viability of microalgae cultivation can be further enhanced by providing recycled nutrients from wastewater sources, thus reducing the fertiliser and freshwater requirements [10]. For example, microalgae strains Hindakia tetrachotoma, Parachlorella hussii, and Chlorella luteoviridis were previously shown to be efficient at growing efficiently municipal wastewater and assimilate ammonium and phosphate from this source $[11,12]$.

However, there are still several obstacles that limit the affordable production of these bioproducts. In particular, biofuels derived from microalgae are low value and require efficiencies in many stages of production to be cost effective [13]. In addition, the thickness of the cell walls of many microalgae species, such as Chlorella spp., Haematococcus pluvialis and Nannochloropsis spp., is a major factor in the cost of extracting metabolites and chemicals $[14,15]$. Therefore, there is a need to improve the efficiency of cell wall degradation in order to make the overall extraction and production of microalgal chemicals and metabolites commercially viable. Furthermore, 
the consideration of microalgae as a biorefinery whereby multiple added-value components are utilised from the biomass, should increase the economic and sustainable viability of microalgal cultivation [2]. For example, following the extraction of lipids or pigments, residual carbohydrates in cell wall and starch materials may be used for biofuel generation after saccharification has been performed.

While amylose and amylopectin polymers from starch granules are a significant source of glucose sugars, microalgal cell walls, which may be composed of polymers such as cellulose, hemicellulose, chitin and pectin [16], are also a major source of various sugars, including rhamnose, xylose, mannose, galactose, glucose, glucuronic acid and glucosamine [17]. For example, a Parachlorella kessleri strain was shown to have a rigid fibrillar cell wall composed of glucosamine and an amorphous cell wall matrix with high abundance of xylose and glucose [18], while Chlorella vulgaris strains were found to also contain rigid glucosamine cell walls with an amorphous matrix rich in rhamnose and galactose but with lower proportions of glucose [17]. Various physical or chemical methods have been employed to degrade microalgae cell walls, including homogenisation, sonication, microwave treatment, heat treatment, and acid or alkaline lysis, all with variable efficiencies [19, 20]. Enzymatic degradation (either alone or in combination with physicochemical treatments) and saccharification has also been tested through use of various commercial enzymes, including cellulase, chitinase, $\beta$ glucuronidase, lysozyme, and pectinase [15, 20-22].

A criticism with the use of such commercial enzymes is that they have not been customised for the degradation of microalgal biomass. Therefore the aim of this study was to investigate the degradation of microalgal biomass by microorganisms that have been selected specifically for their ability to colonise and degrade this type of biomass. Consequently, this approach is more likely to produce degrading enzymes that are better adapted and more efficient for the break down and saccharification of microalgal biomass. Although bacteria can also play a role in degrading microalgal biomass [23], 
this study only focussed on the isolation and identification of fungi since these organisms are regarded as an important source of biomass degrading enzymes [24].

Native filamentous fungal species were isolated using a soil-microalgal solid-state fermentation approach and then crude enzyme extracts from selected fungal strains were tested for efficient saccharification of intact or lipid-extracted C. vulgaris biomass. To our knowledge, this is the first study that has selected fungal strains from a microalgal carbon source and investigated their use in microalgal biomass saccharification.

\section{Materials and methods}

\subsection{Microalgae strains and biomass production}

Three microalgae strains were used to screen for fungal degraders. Strains of $P$. hussii, H. tetrachotoma and Jaagichlorella luteoviridis (recently reclassified from $C$. luteoviridis [25]) were previously isolated from municipal waste water treatment effluent [11]. The P. hussii, H. tetrachotoma and J. luteoviridis strains were maintained on Trisacetate-phosphate (TAP) agar media, as described previously [11] at $25^{\circ} \mathrm{C}$ and $\mathrm{pH} 7.0$ under $150 \mu \mathrm{mol}$ photons $\mathrm{m}^{-2} \mathrm{~s}^{-1}$ light intensity with a 16:8 $\mathrm{h}$ light/dark cycle and subcultured onto fresh media every two weeks. The strains were also maintained in liquid TAP medium at the same growth conditions with continuous agitation at $150 \mathrm{rpm}$ on an orbital shaker. In order to produce sufficient amounts of microalgal biomass for degradation studies, strains were cultivated in $1.5 \mathrm{~L}$ of TAP media in $2 \mathrm{~L}$ Erlenmeyer flasks and incubated for up to 28 days before harvesting. Biomass was harvested by centrifugation at $11,000 \mathrm{~g}$ for $15 \mathrm{~min}$. The pellet was suspended in distilled water and re-centrifuged to remove excess salts. Harvested biomass was collected in Petri dishes and dried at $45^{\circ} \mathrm{C}$ to constant weight. Dried biomass was ground in a mortar and pestle and stored dry and dark at room temperature until required. C. vulgaris was purchased 
123 as dried powder (Chlorella Europe, Wych Cross, UK) for use in saccharification 124 studies.

\subsection{Burial of microalgal biomass in soil}

Commercial topsoil (Online Turf, Ormskirk, UK) was sieved using a metal sieve with a pore size of $4 \mathrm{~mm}$. Moisture content (\% w/w) of the soil was determined by weighing $10 \mathrm{~g}$ of sieved soil in triplicate $\left(\mathrm{wt}_{\mathrm{i}}\right)$ in empty pre-weighed Petri dishes. The dishes were then incubated at $50^{\circ} \mathrm{C}$ to constant weight and re-weighed $\left(\mathrm{wt}_{\mathrm{f}}\right)$. The moisture content $(\% \mathrm{w} / \mathrm{w})$ was calculated using the formula:

Moisture content $(\% \mathrm{w} / \mathrm{w})=\frac{\left(w_{\mathrm{t}}\right)-\left(\mathrm{wt}_{\mathrm{f}}\right)}{\left(w_{\mathrm{i}}\right)} \times 100$

Plastic $1 \mathrm{~L}$ containers $(19.5 \mathrm{~cm} \times 14 \mathrm{~cm} \times 6 \mathrm{~cm})$ were surface sterilised using $70 \%$ ethanol, air-dried and filled to two thirds of their maximum capacity with sieved soil. Nylon mesh bags $(4 \mathrm{~cm} \times 3 \mathrm{~cm})$ with a pore size of $\leq 100 \mu \mathrm{m}$ (Sigma-Aldrich, Dorset, UK) were filled with $500 \mathrm{mg}$ of $P$. hussii, H. tetrachotoma or J. luteoviridis biomass and sealed. Five independent replicates for each strain were prepared then each mesh bag was placed at a depth of $1 \mathrm{~cm}$ from the surface of the soil. Each container was weighed and placed in a $25^{\circ} \mathrm{C}$ incubator. Control boxes of sieved soil, which contained no microalgal biomass were included as negative controls. Moisture content of the soil was adjusted every 2 weeks to $15 \%(w / w)$ using sterile distilled water by weighing the boxes and replacing any water lost by evaporation. Each week the mesh bags were carefully removed, excess surface soil was brushed off and the bags were weighed, using an analytical balance with accuracy to $1 \mathrm{mg}$ (Mettler-Toledo, Leicester, UK), until the net weight of the microalgae samples reached approximately $50 \%$ of their initial weight. 


\subsection{Isolation of microalgal degrading fungal strains}

Microalgae samples were removed from the mesh bags and the contents were serially diluted (at $10^{-1}-10^{-6}$ ) in sterile phosphate buffered saline (PBS) $\mathrm{pH}$ 7.0.

Triplicate volumes of $0.1 \mathrm{~mL}$ from each dilution were then added onto potato dextrose agar (PDA) plates containing $50 \mu \mathrm{g} \mathrm{mL}^{-1}$ chloramphenicol and $0.5 \mathrm{~g} \mathrm{~L}^{-1}$ deoxycholic acid sodium salt to suppress bacterial contamination and reduce the radial size of the colony forming units (CFUs). Plates were incubated at $25^{\circ} \mathrm{C}$ for $5-7 \mathrm{~d}$. After the incubation period, the total viable count of the developed CFUs was performed using a colony counter. The CFUs were initially grouped according to their morphology, and then each was isolated and transferred aseptically onto the centre of a fresh PDA plate, supplemented with $50 \mu \mathrm{g} \mathrm{mL}^{-1}$ chloramphenicol to avoid bacterial contamination. PDA plates were incubated at $25^{\circ} \mathrm{C}$ until the fungal isolate occupied most of the surface of the plate. Fungal spores from each isolate were cryopreserved at $-80^{\circ} \mathrm{C}$ for later experiments, when they were recovered by growth on PDA plates at $25^{\circ} \mathrm{C}$.

\subsection{Genomic DNA extraction, PCR amplification and sequencing}

Genomic DNA was extracted from fungal mycelia using the protocol described previously [26]. In order to genetically identify the fugal isolates, the ITS1-5.8S-ITS2 region of the fungal rRNA gene was amplified by PCR using the ITS5-F primer (5'-GGA AGT AAA AGT CGT AAC AAG G-3') and the ITS4-R primer (5'-TCC TCC GCT TAT TGA TAT GC-3') [27] and using the same PCR conditions as described previously [28]. In the cases where PCR failed, the ITS5-F primer was replaced by the ITS1-F primer (5'-CTT GGT CAT TTA GAG GAA GTA A-3') [29]. PCR products were visualised using agarose gel electrophoresis and bands of the expected size ( 500-700 bp) were purified using a PCR Purification Kit (Qiagen, Manchester, UK) following the manufacturer's instructions. Samples were sequenced by Sanger sequencing at the 
174 University of Manchester sequencing facility. All sequence reads were deposited in the

175 NCBI GenBank database under the following accession numbers: MN535081 (isolate

176 C. S1), MN535082 (isolate C. S4), MN535083 (isolate C. S5), MN535084 (isolate J.L

177 S1), MN535085 (isolate J.L S2), MN535086 (isolate J.L S3), MN535087 (isolate J.L

178 S5), MN535088 (isolate H.T S1), MN535089 (isolate H.T S2), MN535090 (isolate H.T

179 S3), MN535091 (isolate H.T S6), MN535092 (isolate H.T S7), MN535093 (isolate P.H

S4), MN535094 (isolate P.H S5), MN535095 (isolate P.H S6).

\subsection{Bioinformatic analysis}

ITS sequence reads were viewed using Finch TV v1.4.0 software (Geospiza,

Seattle, WA, USA). Sequences were initially analysed by NCBI BLAST to determine the identical or most closely matched NCBI database sequences in order to identify identical or related strains and species. The identification by NCBI BLAST was further confirmed by the morphological characteristics of each isolate. Phylogenetic relationships of the isolated fungal sequences were compared with sequences of closely related fungi selected from NCBI GenBank database. All ITS sequences were aligned using ClustalW in the MEGA7 software. Aligned sequences were used to construct neighbour-joining trees and robustness of each branch was estimated by bootstrapping of 1,000 samples. Evolutionary analyses were conducted in MEGA7 [30]. vulgaris biomass as the sole carbon source. Mycelia plugs $(13 \mathrm{~mm})$ made of the fungal isolates that had been grown on PDA plates were transferred to the centre of the 
$25^{\circ} \mathrm{C}$ until fungal growth covered the whole plate. The mycelia plugs were removed and the agar was roughly chopped using a sterile blade. Chopped fungal agar from two replicate plates were combined and extracted in a flask containing $25 \mathrm{~mL}$ of extraction buffer (100 mM sodium acetate, $20 \mathrm{mM}$ sodium chloride and $0.02 \%(\mathrm{w} / \mathrm{v})$ sodium azide, $\mathrm{pH}$ 5.5) followed by incubation on an orbital shaker at $180 \mathrm{rpm}$ at room temperature for $2.25 \mathrm{~h}$ in aseptic conditions, as described previously [32]. Extracted enzymes were then filtered through double layered sterile tissue and filtrates were centrifuged at $12,470 \mathrm{~g}$ at $4^{\circ} \mathrm{C}$ for $10 \mathrm{~min}$. The resultant supernatants were passed through a sterile syringe filter $(0.22 \mu \mathrm{m})$ and stored at $4^{\circ} \mathrm{C}$ until required.

\subsection{Saccharification of intact and lipid extracted microalgal biomass}

To assess the efficiency of the isolated fungal enzyme extracts on a commercially used microalgal strain, and due to the high volume of biomass required for these saccharification experiments, commercially supplied dry $C$. vulgaris biomass was used. To obtain the lipid extracted C. vulgaris biomass, an extraction method was performed essentially as described [21], whereby $200 \mathrm{~mL}$ chloroform:methanol (1:2 ratio) was added to $30 \mathrm{~g}$ of intact $C$. vulgaris biomass in a glass beaker and mixed on a magnetic stirrer (Bibby Scientific, Stone, UK) overnight at $50^{\circ} \mathrm{C}$ in a fume hood. The sample was filtered using Whatman GF/C filter paper (diameter $47 \mathrm{~mm}$, GE Healthcare, UK) then the remaining residual biomass was dried at $50^{\circ} \mathrm{C}$ until it reached a constant weight. Total lipid concentration from biomass was determined essentially as described previously [11].

The fungal crude enzyme extract degradation of $C$. vulgaris biomass was carried out in flat-bottom 96-well microtiter plates where $90 \mu \mathrm{L}$ of $C$. vulgaris biomass (30 mg $\left.\mathrm{mL}^{-1}\right)$ suspended and autoclaved in $50 \mathrm{mM}$ sodium acetate buffer ( $\left.\mathrm{pH} 5.5\right)$ were added to wells along with $90 \mu \mathrm{L}$ of enzyme extract and incubated at $37^{\circ} \mathrm{C}$ for $70 \mathrm{~h}$. Control treatments to determine background baseline values contained only biomass without 
enzyme extract or enzyme extract without biomass. Samples were taken periodically at different time points, centrifuged at $900 \mathrm{~g}$ for $10 \mathrm{~min}$ and the concentration of reducing sugars, which represents the enzymatic saccharification of the $C$. vulgaris biomass, were estimated in the supernatant as described [32] using 3,5-dinitrosalicylic acid (DNS) reagent prepared as described previously [33]. Glucose concentration was determined by comparison to a glucose standard (concentration range $0.25-5 \mathrm{mg} \mathrm{mL}$ $\left.{ }^{1}\right)$. For calculation of saccharification efficiency (\%), the following formula was used: Saccharification efficiency $(\%)=\frac{\text { Reducing sugars in sample }(\mathrm{mg} / \mathrm{mL})}{\text { Total carbohydrates in sample }(\mathrm{mg} / \mathrm{mL})} \times 100$ In order to determine the efficiency of extracted fungal crude enzymes on liberating reducing sugars from $C$. vulgaris biomass, enzyme activity was determined in units $(U)$ per $\mathrm{mL}$ of enzyme extract, where $1 \mathrm{U}$ was defined as the amount of fungal crude extract to release $1 \mu \mathrm{mol}$ glucose per min from intact $C$. vulgaris biomass under the studied saccharification conditions. The total carbohydrate concentration of the biomass was determined by measuring the concentration of reducing sugars in biomass that was treated by acid hydrolysis in $0.5 \mathrm{M} \mathrm{H}_{2} \mathrm{SO}_{4}$ at $121^{\circ} \mathrm{C}$ for $20 \mathrm{~min}$. Starch concentration in the $C$. vulgaris biomass was measured essentially as described previously [34] using a Megazyme Total Starch analysis kit (Megazyme International, Wicklow, Ireland). The concentration of cell wall derived sugars was determined using an adapted method [35] whereby $25 \mathrm{mg}$ of dried biomass was digested in $1.5 \mathrm{~mL}$ of the acetic acid/nitric acid reagent $\left(150 \mathrm{~mL}\right.$ of $80 \%(\mathrm{v} / \mathrm{v}) \mathrm{CH}_{3} \mathrm{COOH}, 15 \mathrm{~mL}$ concentrated nitric acid (Fisher Scientific, Loughborough, UK)) at $100^{\circ} \mathrm{C}$ for 30 min then the residual biomass was washed in water, followed by incubation in $1.25 \mathrm{~mL}$ of $67 \%(\mathrm{v} / \mathrm{v}) \mathrm{H}_{2} \mathrm{SO}_{4}$ at room temperature for $1 \mathrm{~h}$ by shaking to solubilise cell wall polymers. The samples were mixed with $1 \mathrm{~mL}$ of $0.2 \%(\mathrm{w} / \mathrm{v})$ anthrone reagent (Merck, Hohenbrunn, Germany) in concentrated $\mathrm{H}_{2} \mathrm{SO}_{4}$ then incubated at $100^{\circ} \mathrm{C}$ for $16 \mathrm{~min}$, cooled to room temperature 
and the absorbance measured at $630 \mathrm{~nm}$. Sugar concentration was determined by comparison to a cellulose standard (concentration range $20-200 \mu \mathrm{mL}^{-1}$ ).

\subsection{Statistical analysis}

Statistical analysis of the data by ANOVA with the significance threshold set at $p$ value $<0.05$ was performed using GraphPad Prism version 7.01 for Windows (GraphPad Software, La Jolla, USA).

\section{Results}

\subsection{Degradation of microalgal biomass in soil}

Dried J. luteoviridis, $H$. tetrachotoma and $P$. hussii biomass was incubated in soil at $25^{\circ} \mathrm{C}$ for an 8 week time period with a moisture content maintained at $15 \%(\mathrm{w} / \mathrm{v})$ to ensure the required humidity for microbial growth and microbial-derived degradation of the microalgal biomass. During the initial weeks of incubation, the water loss from the soil ranged between 20 and $35 \%$ but in the later weeks until the end of the incubation period there was less water loss $(10-15 \%)$. Each microalgal strain sample displayed a significant decrease in biomass weight during the 8 weeks of incubation, indicative of the degradation process (Fig. 1). Occasional temporary increase in biomass was observed at some time points (at weeks 2 and 7 for J. luteoviridis and $H$. tetrachotoma and at week 4 for $P$. hussii), which was likely due to rehydration of the dried biomass when water was added to maintain the moisture content. By the end of incubation period at week 8 , the percentage of biomass weight loss was $59.4 \%$ for $\mathrm{J}$. luteoviridis, $45.4 \%$ for $H$. tetrachotoma and $63.7 \%$ for $P$. hussii biomass (Fig. 1). 


\subsection{Quantification of fungal growth}

For all three types of the degraded microalgal biomass, there were significantly higher $(p<0.05)$ total viable fungal counts present when compared to the negative control, which was soil without added biomass (Fig. 2). The highest viable fungal count was associated with the $P$. hussii biomass $\left(2.5 \times 10^{7} \mathrm{CFU}\right)$, which was the biomass that exhibited the largest degradation in terms of weight loss (Fig. 1). There was no significant difference in viable fungal counts between the residual biomass of $\mathrm{J}$. luteoviridis and $H$. tetrachotoma $(p>0.05)$, while both of these strains exhibited significantly lower viable fungal loads than the $P$. hussii sample $(p<0.05)$.

\subsection{Identification of isolated fungal strains}

The quantification of fungal growth, and consequently the fungal strain isolation process, was conducted at the end of the 8-week incubation period. The recovered fungal strains from the different samples of residual microalgal biomass were identified based on morphological characteristics of recovered isolates on PDA plates (Fig. 3) followed by genetic identification by amplifying and sequencing the ITS1-5.8S-ITS2 region of fungal rRNA genes (Table 1). Phylogenetic analysis corroborated the taxonomic identification made by the BLAST analysis in nearly all cases (Fig. 4). All isolates were classified as filamentous fungi. More fungal isolates were recovered from $P$. hussii and $H$. tetrachotoma biomass although some strains were found to be identical species; for example, two strains of $F$. solani from the $P$. hussii biomass. One of the F. solani isolates (strain P.H S1) was also isolated from $H$. tetrachotoma biomass (Table 1). Likewise, a strain of Circinella chinensis was recovered from $P$. hussii and $H$. tetrachotoma biomass, while a strain of Aphanoascus verrucosus was isolated from biomass of all three microalgae. Most isolates belong to the Ascomycota phylum while only $A$. elegans and $C$. chinensis belong to the Zygomycota phylum. F. solani was the predominant species that was isolated from all sources of microalgal residual biomass, 
which accounted for $60-70 \%$ of all fungal isolates. None of the fungal isolates extracted from the negative control (with no microalgal biomass) were identified in any of the microalgal biomass (Table 1).

Comparison of the sequences extracted from these isolates was conducted by pairwise sequence alignment and it was found that the $P$. hussii biomass $F$. solani isolates P.H S1 and P.H S5 have $99.6 \%$ sequence similarity, respectively, indicating that these pairs represented the same species although each individual isolate showed slight differences in their morphological characteristics (Fig. 3c). The phylogenetic analysis also indicated that all isolated $F$. solani strains were related (Fig. 4). The Fusarium oxysporum strain (P.H S6) isolated from P. hussii biomass did not group with other known $F$. oxysporum strains, possibly suggesting that the strain may have been mis-identified.

\subsection{Saccharification of Chlorella vulgaris by fungal enzyme extracts}

Fungal enzyme extracts were produced from F. solani J.L S1, A. elegans J.L S2, and D. nanus J.L S3, which were isolated from J. luteoviridis residual degraded biomass. These fungal strains were selected because it was hypothesised that strains that are able to degrade $J$. luteoviridis may also be efficient at saccharifying $C$. vulgaris biomass, since both species share taxonomic similarity [11]. The $C$. vulgaris biomass had a mean total carbohydrate content of $17.3 \%(\mathrm{w} / \mathrm{w})$. When starch-derived sugars and cell wall-derived sugars were determined individually, the mean starch concentration was $5.8 \%(\mathrm{w} / \mathrm{w})$ while the mean cell wall releasable sugar concentration was $10.4 \%(w / w)$. All fungal crude enzyme extracts tested were able to release reducing sugars from $C$. vulgaris biomass (Fig. 5). They gave enzyme activity values of $0.043 \pm 0.002 \mathrm{U} \mathrm{mL}^{-1}$ for the $A$. elegans extract, $0.053 \pm 0.007 \mathrm{U} \mathrm{mL}^{-1}$ for the $D$. nanus extract, and $0.044 \pm 0.002 \mathrm{U} \mathrm{mL}^{-1}$ for the $F$. solani extract. For intact $C$. vulgaris biomass, there were only very minor differences between the three extracts (Fig. 5a). 
However, a significantly higher $(p<0.05)$ concentration of reducing sugar was released after $70 \mathrm{~h}$ of incubation with $D$. nanus extract, equivalent to $57 \%$ of total $C$. vulgaris carbohydrate, compared to the incubation with the extracts from $A$. elegans and $F$. solani (Table 2$)$, which were not significantly different $(p>0.05)$.

The C. vulgaris biomass had a mean total lipid content of $14.7 \%(\mathrm{w} / \mathrm{w})$. Further saccharification analysis was performed with the fungal crude enzyme extracts on the residual biomass following extraction of the lipids. The concentration of released reducing sugars from lipid-extracted $C$. vulgaris biomass was higher than from intact $C$. vulgaris biomass, and there was greater variation between the different fungal extracts (Fig. 5). There were consistently higher saccharification efficiency values for each extract when incubated with the lipid-extracted biomass (Table 2). Treating lipidextracted $C$. vulgaris biomass with $D$. nanus crude extracts resulted in the release of $76 \%$ of carbohydrates, which was significantly higher $(p<0.05)$ compared to all other used fungal extracts.

\section{Discussion}

There are many species of fungi in all ecosystems that play an important role in the degradation and recycling of biomass. For example, indigenous fungi that are rich in soil have various roles in decomposing biomass while marine fungi can also play a role in plant and algal bioconversion [24, 36]. Although the microalgal biomass degradation that occurred in the soil may not have been completely due fungal activity, most fungal strains can grow within the temperature range $\left(25-30^{\circ} \mathrm{C}\right)$ of the incubation conditions [37] and it was expected that the majority of the microalgal biomass degradation was due to fungal activity. To our knowledge, a soil incubation approach has not previously been used to identify novel fungal degraders of microalgal biomass and very little is known about fungal organisms that can mediate the degradation of microalgal material. Knowledge of fungal degradation of algal biomass 
361 is mostly from marine environments, where marine fungi have been shown to be associated with and degrade green and brown seaweed [38-40].

The abundance of Ascomycota from this soil-microalgal fermentation screen suggests that they are efficient at colonising algae biomass. A previous analysis of a marine green macroalga Flabellia petiolata found that its natural fungal microbiome was also dominated by Ascomycota [40]. Very few studies have examined fungal species associated with Chlorophyta, especially microalgae, and while there is some evidence of a fungal (Acremonium sp.) symbiosis with Chlorella sorokiniana [41], there is no previous evidence of saprophytic fungi associating with microalgae. The predominance of Fusarium isolates in this study is interesting since most Fusarium species are soil saprophytes and are significant plant pathogens [42], and therefore their ability to penetrate host tissues via their enzymatic capacity can be exploited. For instance, the capacity of cell wall degrading enzymes of $F$. oxysporum to saccharify corn stalk and switchgrass [32] as well as lignin degradation by F. solani [43] has previously been demonstrated. The potential microalgal biomass degraders should be attached to the surface of the algal biomass for the degradation process to occur, as demonstrated previously in studies concerning fungal degradation of different polymers $[28,44,45]$. However, to ensure that the isolated fungal strains are mainly responsible for degradation of biomass and not simply present within the soil but with no role in degradation, future studies may need to monitor the isolation of fungal strains at earlier time points rather than only at the end of the process.

Previous studies that treated microalgal biomass with a cocktail of specified commercial cell wall degrading enzymes demonstrated the release of $10 \%$ of the carbohydrate sugars from $C$. sorokiniana biomass [20], and $76 \%$ of sugars from $C$. vulgaris biomass [46] for subsequent production of bioethanol. However, these extractions also required additional pre-treatment steps, such as use of bead beating, acid or alkaline pre-treatment or microwave radiation in order to extract most of the 
sugars from the cells. Our experiments have demonstrated the efficient capability of fungal crude enzyme for releasing sugars from intact microalgal biomass when this is the only treatment method with no additional physicochemical pre-treatment steps needed. Other studies that used enzymatic pre-treatment for extracting microalgal sugars employed polymers such as cellulose, starch or pectin incorporated within the fungal growth media to trigger the excretion of enzymes by the degrading microorganism [47]. Secretion of degrading enzymes from the fungal strains in this study was achieved using a minimal media incorporated with intact microalgal biomass as a sole carbon source.

One previous study also used crude fungal enzyme extracts to degrade microalgal cells, although in this case the fungal strains, Aspergillus lentulus and Rhizopus oryzae that were used had been isolated from the environment and not isolated from a microalgal carbon source [48]. Consequently the sugar release using enzyme extracts from these strains was fairly modest (10 - 20\% of total sugars), and while one sample of $A$. lentulus enzyme was able to release $44 \%$ of the total sugars, the saccharification efficiency was less than achieved here with the enzyme extract from $D$. nanus. Of the three sets of enzyme extract tested here, the $D$. nanus derived sample was the most efficient. This may suggest that the crude extract from the $D$. nanus isolate contained higher enzyme abundance or more efficient degrading enzymes that may be more compatible with the polysaccharides present in $C$. vulgaris compared to the enzyme extracts from $A$. elegans and $F$. solani.

Efficient utilisation of microalgal biomass will require exploitation of all available products for maximum efficiency [2], thus lipids can be extracted for uses such as for biodiesel production, while carbohydrates can then be released from the residual biomass such as for bioethanol production. Therefore we examined the saccharification of residual $C$. vulgaris biomass following lipid extraction and observed that the sugar release was higher from this biomass compared to the intact biomass. The lipid 
extraction process included solvent extraction with a mixture of chloroform:methanol coupled with high temperature $\left(40-50^{\circ} \mathrm{C}\right)$ and a drying process, therefore it is expected that the complexity of cell wall bonds will weaken. In support of this, it has been previously demonstrated that lipid extraction by chloroform:methanol solvent treatment elicits some cell wall damage as determined by the presence of disrupted and distorted cells, although this is not as damaging to cell wall structure as sonication, which causes substantial disruption of cells [49]. Future work will be needed to fully examine exactly how the cell wall structure changes in response to these treatments.

We therefore suggest that weakening of the $C$. vulgaris cell wall caused by the solvent treatment may have facilitated the enzymatic degradation and explained the higher release of sugars compared to from the intact biomass, and therefore this could be considered as a pre-treatment.

In conclusion, we have demonstrated the ability to isolate fungal strains that can be sources of novel enzymes to efficiently break down and release sugars from microalgal biomass. Crude enzymes from $D$. nanus showed the highest saccharification efficiency followed by $A$. elegans and $F$. solani. The saccharification efficiency was significantly higher in lipid-extracted biomass than in intact biomass, indicating the benefit of utilising microalgal biomass for multiple products. The saccharification conditions were maintained at $37^{\circ} \mathrm{C}$ and $\mathrm{pH} 5.5$ to ensure the enzymes responsible for the biomass degradation. 


\section{Acknowledgements}

443 M. K. Monjed thanks Umm Al-Qura University, Ministry of Education, Saudi Arabia for 444 providing a PhD scholarship. We are grateful to Dr Olumayowa Osundeko for providing microalgae strains.

446

\section{References}

D. Gangl, J.A.Z. Zedler, P.D

P.D. Rajakumar, E.M.R. Martinez, A. Riseley, A.

Włodarczyk A, S. Purton, Y. Sakuragi, C.J. Howe, P.E. Jensen, C. Robinson, Biotechnological exploitation of microalgae, J. Exp. Bot. 66 (22) (2015) 6975-6990. [2] K.W. Chew, J.Y. Yap, P.L. Show, N.H. Suan, J.C. Juan, T.C. Ling, D.-J. Lee, J.-

S. Chang, Microalgae biorefinery: High value products perspectives, Bioresour. Technol. 229 (2017) 53-62.

454 [3] J. Ruiz, G. Olivieri, J. de Vree, R. Bosma, P. Willems, J.H. Reith, M.H.M.

455 Eppink, D.M.M. Kleinegris, R.H. Wijffels, M.J. Barbosa, Towards industrial products 456 from microalgae, Energ. Environ. Sci. 9 (10) (2016) 3036-3043.

457 [4] M.I. Khan, J.H. Shin, J.D. Kim, The promising future of microalgae: current status, challenges, and optimization of a sustainable and renewable industry for biofuels, feed, and other products, Microb. Cell Fact. 17 (1) (2018) 36.

460 [5] Y. Chisti, Biodiesel from microalgae, Biotechnol. Adv. 25 (3) (2007) 294-306.

461 [6] R.P. John, G.S. Anisha, K.M. Nampoothiri, A. Pandey, Micro and macroalgal 462 biomass: A renewable source for bioethanol, Bioresour. Technol. 102 (1) (2011) 186463193.

464 [7] K. Gao, V. Orr, L. Rehmann, Butanol fermentation from microalgae-derived 465 carbohydrates after ionic liquid extraction, Bioresour. Technol. 206 (2016) 77-85.

466 [8] A. Demirbas, Biofuels securing the planet's future energy needs, Energ.

467 Convers. Manage. 50 (9) (2009) 2239-2249. 
468 [9] A. Singh, P.S. Nigam, J.D. Murphy, Renewable fuels from algae: An answer to 469 debatable land based fuels, Bioresour. Technol. 102 (1) (2011) 10-16.

470 [10] J.K. Pittman, A.P. Dean, O. Osundeko, The potential of sustainable algal biofuel 471 production using wastewater resources, Bioresour. Technol. 102 (1) (2011) 17-25.

472 [11] O. Osundeko, H. Davies, J.K. Pittman, Oxidative stress-tolerant microalgae 473 strains are highly efficient for biofuel feedstock production on wastewater, Biomass $474 \quad$ Bioenergy 56 (2013) 284-294.

475 [12] O. Osundeko, J.K. Pittman, Implications of sludge liquor addition for 476 wastewater-based open pond cultivation of microalgae for biofuel generation and 477 pollutant remediation, Bioresour. Technol. 152 (2014) 355-363.

478 [13] Y. Chisti, Constraints to commercialization of algal fuels, J. Biotechnol. 167 (3) $479 \quad$ (2013) 201-214.

480 [14] S.Y. Lee, J.M. Cho, Y.K. Chang, Y.-K. Oh, Cell disruption and lipid extraction 481 for microalgal biorefineries: A review, Bioresour. Technol. 244 (2017) 1317-1328.

482 [15] H.G. Gerken, B. Donohoe, E.P. Knoshaug, Enzymatic cell wall degradation of 483 Chlorella vulgaris and other microalgae for biofuels production, Planta 237 (1) (2013) $484 \quad 239-253$.

485 [16] P.-H. Baudelet, G. Ricochon, M. Linder, L. Muniglia, A new insight into cell walls 486 of Chlorophyta, Algal Res. 25 (2017) 333-371.

487 [17] H. Takeda, Sugar composition of the cell wall and the taxonomy of Chlorella 488 (Chlorophyceae), J. Phycol. 27 (2) (1991) 224-232.

489 [18] Á.B. Juárez, C.G. Vélez, A.R. Iñiguez, D.E. Martínez, M.C. Rodríguez, M.S. 490 Vigna, M. del Carmen Ríos de Molina, A Parachlorella kessleri (Trebouxiophyceae, 491 Chlorophyta) strain from an extremely acidic geothermal pond in Argentina, Phycologia $49250(4)(2011) 413-421$.

493 [19] R. Halim, R. Harun, M.K. Danquah, P.A. Webley, Microalgal cell disruption for 494 biofuel development, Appl. Energ. 91 (1) (2012) 116-121. 
carbohydrates in microalgal biomass by physical, chemical and enzymatic pretreatments as a previous step for bioethanol production, Chem. Eng. J. 262 (2015) 939-945.

[21] O.K. Lee, A.L. Kim, D.H. Seong, C.G. Lee, Y.T. Jung, J.W. Lee, E.Y. Lee,

Chemo-enzymatic saccharification and bioethanol fermentation of lipid-extracted

501 residual biomass of the microalga, Dunaliella tertiolecta, Bioresour. Technol. 132 (2013) 197-201.

[22] A.-M. Aguirre, A. Bassi, Investigation of an integrated approach for bio-crude recovery and enzymatic hydrolysis of microalgae cellulose for glucose production, Can. J. Chem. Eng. 94 (2) (2016) 238-243. [23] F. Lü, J. Ji, L. Shao, P. He, Bacterial bioaugmentation for improving methane and hydrogen production from microalgae, Biotechnol. Biofuels 6 (1) (2013) 92. [24] J. van den Brink, R.P. de Vries, Fungal enzyme sets for plant polysaccharide degradation, Appl. Microbiol. Biotechnol. 91 (6) (2011) 1477.

511 (Trebouxiophyceae, Chlorophyta) and its close relatives: an evolutionary puzzle, 512 Phytotaxa 388 (1) (2019) 22.

513 [26] J. Feng, R. Hwang, K.F. Chang, S.F. Hwang, S.E. Strelkov, B.D. Gossen, Q. 514 Zhou, An inexpensive method for extraction of genomic DNA from fungal mycelia, Can.

515 J. Plant Pathol. 32 (3) (2010) 396-401.

516 [27] T.J. White, T. Bruns, S. Lee, J. Taylor, Amplification and direct sequencing of

517 fungal ribosomal RNA genes for phylogenetics, in: M.A. Innis, D.H. Gelfand, J.J.

518 Sninsky, T.J. White (Eds.), PCR Protocols, Academic Press, San Diego, 1990, pp. 315519 322. 
520 [28] U. Zafar, A. Houlden, G.D. Robson, Fungal communities associated with the

521 biodegradation of polyester polyurethane buried under compost at different

522 temperatures, Appl. Environ. Microbiol. 79 (23) (2013) 7313.

523 [29] M. Gardes, T.D. Bruns, ITS primers with enhanced specificity for

524 basidiomycetes - application to the identification of mycorrhizae and rusts, Mol. Ecol. 2 $525 \quad$ (2) (1993) 113-118.

526 [30] S. Kumar, G. Stecher, K. Tamura, MEGA7: Molecular Evolutionary Genetics

527 Analysis Version 7.0 for bigger datasets, Mol. Biol. Evol. 33 (7) (2016) 1870-1874.

528 [31] P. Chand, A. Aruna, A.M. Maqsood, L.V. Rao, Novel mutation method for

529 increased cellulase production, J. Appl. Microbiol. 98 (2) (2005) 318-323.

530 [32] B.C. King, M.K. Donnelly, G.C. Bergstrom, L.P. Walker, D.M. Gibson, An

531 optimized microplate assay system for quantitative evaluation of plant cell wall-

532 degrading enzyme activity of fungal culture extracts, Biotechnol. Bioeng. 102 (4) (2009)

$533 \quad 1033-1044$.

534 [33] G.L. Miller, Use of dinitrosalicylic acid reagent for determination of reducing 535 sugar, Anal. Chem. 31 (3) (1959) 426-428.

536 [34] A.K. Bajhaiya, A.P. Dean, T. Driver, D.K. Trivedi, N.J.W. Rattray, J.W. Allwood, 537 R. Goodacre, J.K. Pittman, High-throughput metabolic screening of microalgae genetic 538 variation in response to nutrient limitation, Metabolomics 12 (1) (2016) 9.

539 [35] D.M. Updegraff, Semimicro determination of cellulose in biological materials, $540 \quad$ Anal. Biochem. 32 (3) (1969) 420-424.

541 [36] L. Balabanova, L. Slepchenko, O. Son, L. Tekutyeva, Biotechnology potential of 542 marine fungi degrading plant and algae polymeric substrates, Front. Microbiol. 9 (2018) 5431527.

544 [37] J. Pietikäinen, M. Pettersson, E. Bååth, Comparison of temperature effects on 545 soil respiration and bacterial and fungal growth rates, FEMS Microbiol. Ecol. 52 (1) $546 \quad$ (2005) 49-58. 
547 [38] N. Trivedi, C.R.K. Reddy, R. Radulovich, B. Jha, Solid state fermentation

548 (SSF)-derived cellulase for saccharification of the green seaweed Ulva for bioethanol 549 production, Algal Res. 9 (2015) 48-54.

550 [39] R.P. Singh, V. Gupta, P. Kumari, M. Kumar, C.R.K. Reddy, K. Prasad, B. Jha,

551 Purification and partial characterization of an extracellular alginate lyase from

552 Aspergillus oryzae isolated from brown seaweed, J. Appl. Phycol. 23 (4) (2011) 755-

553762.

554 [40] G. Gnavi, L. Garzoli, A. Poli, V. Prigione, G. Burgaud, G.C. Varese, The

555 culturable mycobiota of Flabellia petiolata: First survey of marine fungi associated to a

556 Mediterranean green alga, PLOS ONE 12 (4) (2017) e0175941.

557 [41] K. Watanabe, N. Takihana, H. Aoyagi, S. Hanada, Y. Watanabe, N. Ohmura, H.

558 Saiki, H. Tanaka, Symbiotic association in Chlorella culture, FEMS Microbiol. Ecol. 51

$559 \quad$ (2) (2005) 187-196.

560 [42] R. Dean, J.A.L. van Kan, Z.A. Pretorius, K.E. Hammond-Kosack, A. Di Pietro,

561 P.D. Spanu, J.J. Rudd, M. Dickman, R. Kahmann, J. Ellis, G.D. Foster, The Top 10

562 fungal pathogens in molecular plant pathology, Mol. Plant Pathol. 13 (4) (2012) 414-

563430.

564 [43] V.V. Lozovaya, A.V. Lygin, O.V. Zernova, S. Li, J.M. Widholm, G.L. Hartman, 565 Lignin degradation by Fusarium solani f. sp. glycines, Plant Dis. 90 (1) (2006) 77-82.

566 [44] M. Karamanlioglu, A. Houlden, G.D. Robson, Isolation and characterisation of

567 fungal communities associated with degradation and growth on the surface of

568 poly(lactic) acid (PLA) in soil and compost, Int. Biodeterior. Biodegrad. 95 (2014) 301569310.

570 [45] A.S. Al Hosni, J.K. Pittman, G.D. Robson, Microbial degradation of four 571 biodegradable polymers in soil and compost demonstrating polycaprolactone as an 572 ideal compostable plastic, Waste Manage. 97 (2019) 105-114. 
573 [46] K.H. Kim, I.S. Choi, H.M. Kim, S.G. Wi, H.-J. Bae, Bioethanol production from

574 the nutrient stress-induced microalga Chlorella vulgaris by enzymatic hydrolysis and 575 immobilized yeast fermentation, Bioresour. Technol. 153 (2014) 47-54.

576 [47] S.-H. Ho, S.-W. Huang, C.-Y. Chen, T. Hasunuma, A. Kondo, J.-S. Chang,

577 Bioethanol production using carbohydrate-rich microalgae biomass as feedstock,

578 Bioresour. Technol. 135 (2013) 191-198.

579 [48] S.K. Prajapati, A. Bhattacharya, A. Malik, V.K. Vijay, Pretreatment of algal 580 biomass using fungal crude enzymes, Algal Res. 8 (2015) 8-14.

581 [49] A. Ranjan, C. Patil, V.S. Moholkar, Mechanistic assessment of microalgal lipid 582 extraction, Ind. Eng. Chem. Res. 49 (2010) 2979-2985.

583 

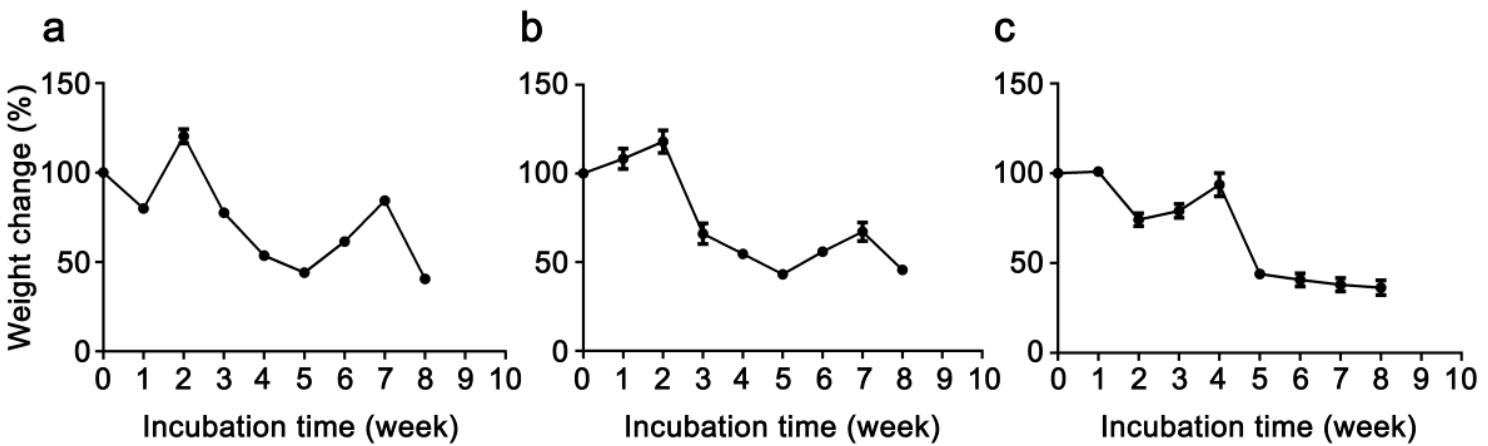

Fig. 1 Microalgae biomass degradation in soil. (a) J. luteoviridis biomass. (b) $H$. tetrachotoma biomass. (c) $P$. hussii biomass. Dried biomass was incubated in soil at $25^{\circ} \mathrm{C}$ for 8 weeks. Each data point represents the mean \pm SEM of five independent replicates.

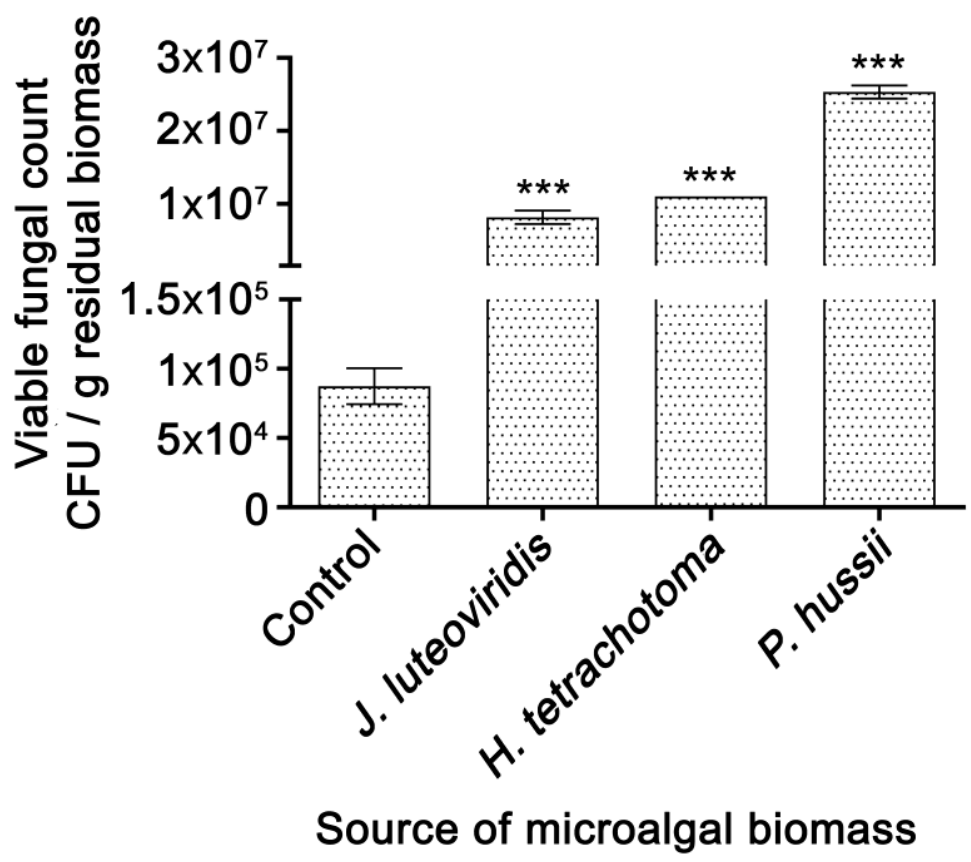

Fig. 2 Fungal growth on degraded microalgal biomass. Total viable fungal counts (CFU) on residual microalgal biomass that was incubated in soil for 8 weeks in comparison to a control (no biomass). Each sample was serially diluted in PBS and incubated on selective PDA plates at $25^{\circ} \mathrm{C}$ for up to 7 days. Each data point represents a mean \pm SEM of three independent replicates. Asterisks above a bar indicate a significant difference $(p<0.05)$ compared to the control. 


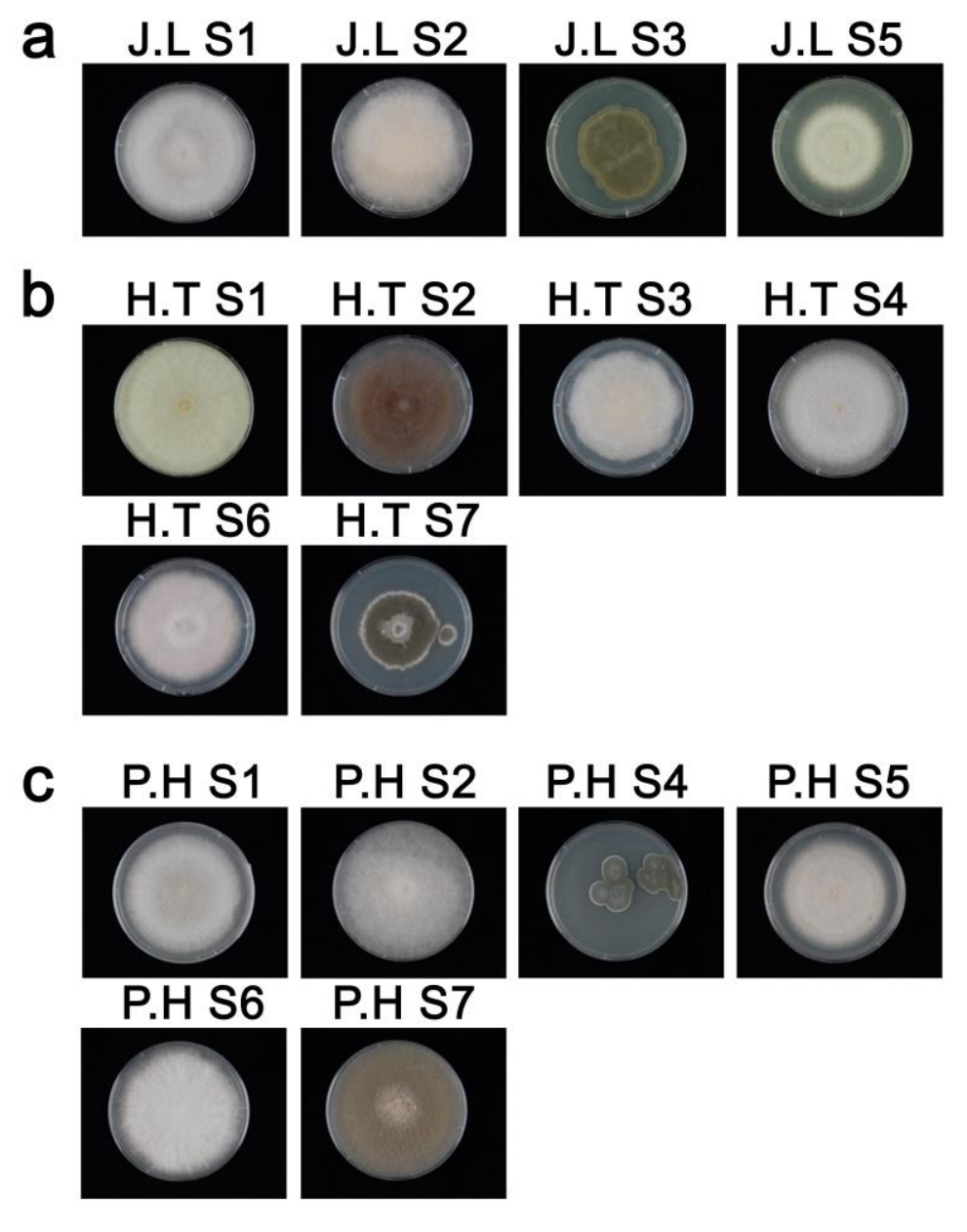

600 Fig. 3 Fungal isolates recovered from degraded residues of microalgae biomass 601 following incubation in soil at $25^{\circ} \mathrm{C}$ for 8 weeks. (a) J. luteoviridis biomass isolates. (b) $H$. tetrachotoma biomass isolates. (c) $P$. hussii biomass isolates. 


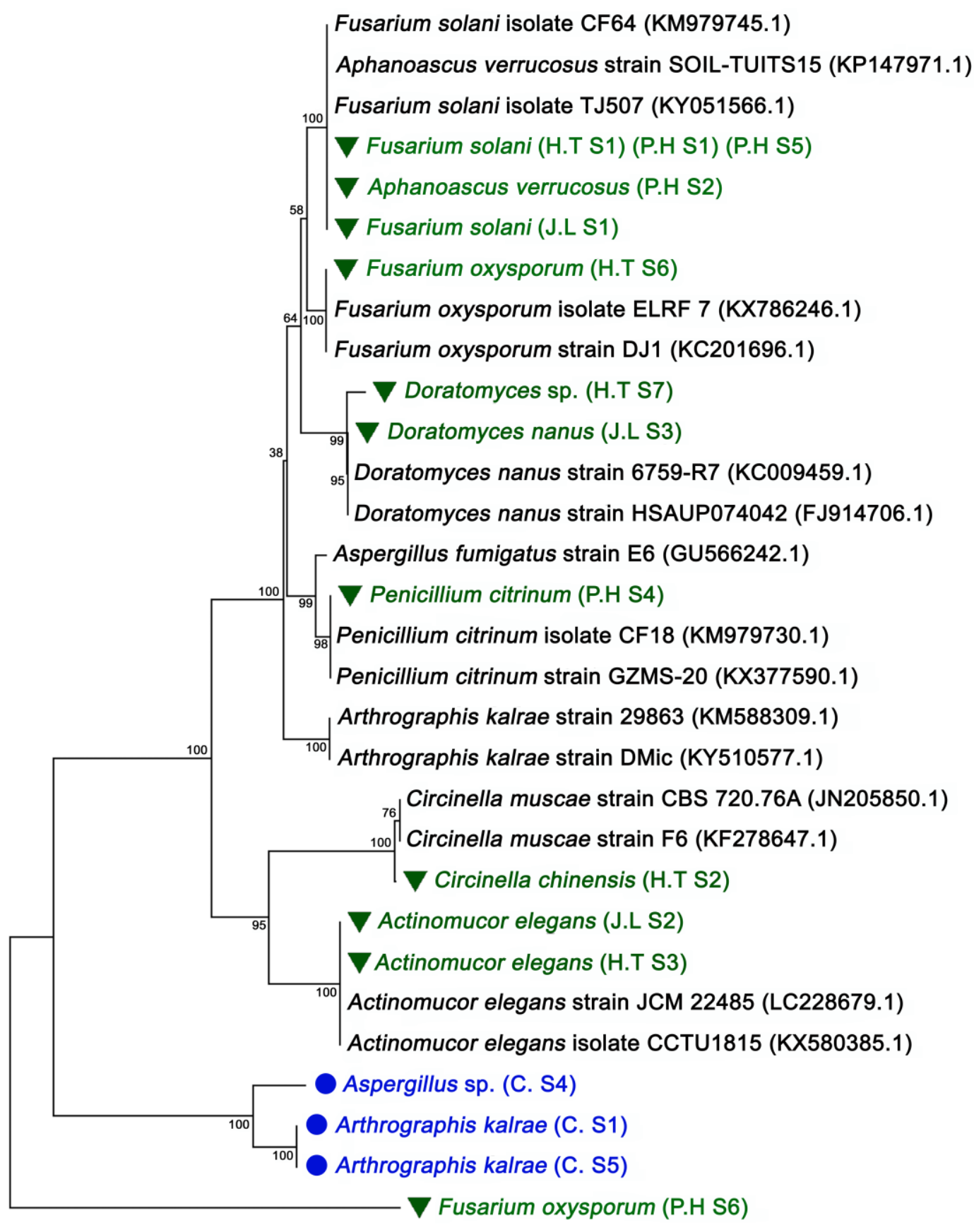

Fig. 4 Phylogenetic tree of fungal isolates recovered from degraded microalgal biomass. A triangle symbol indicates the isolates identified from microalgal biomass and a circle symbol indicates the isolates identified from control soil (no biomass). The microalgal biomass source is indicated (J.L: J. luteoviridis, H.T: H. tetrachotoma, P.H: $P$. hussii). The neighbour-joining tree is based on ITS1-5.8S-ITS2 DNA sequences. Comparison is made with selected sequences from known fungal strains from NCBI GenBank database with accession number provided. Bootstrap values are represented as percentages from 1000 replications. 

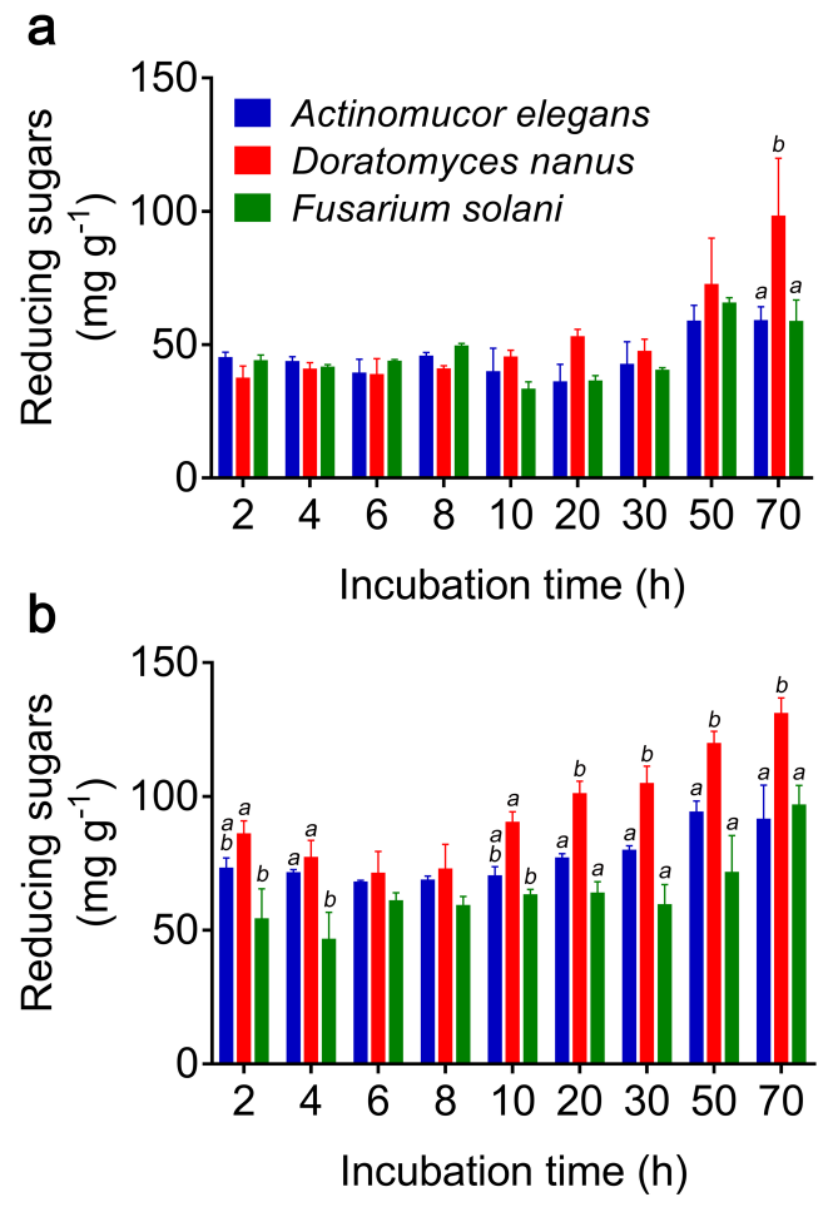

Fig. 5 Saccharification of $C$. vulgaris biomass by fungal crude enzyme extracts. (a) Treatment of intact biomass. (b) Treatment of lipid-extracted biomass. Biomass at a concentration of $1.5 \%(\mathrm{w} / \mathrm{v})$ was incubated with enzyme extracts from $A$. elegans (strain J.L S2), D. nanus (strain J.L S3) and F. solani (strain J.L S1). Each data point represents a mean \pm SEM of three independent replicates. Within each incubation time point that shows significantly different data, values that are significantly different do not share a lowercase letter $(p<0.05)$. 
Table 1 Fungal taxa assignments identified using ITS sequencing of rRNA gene amplification from samples isolated from control conditions or from residual degraded microalgal biomass buried in soil at $25^{\circ} \mathrm{C}$ for 8 weeks. The closest sequence matches from the NCBI GenBank database determined by BLAST are shown.

\begin{tabular}{|c|c|c|c|}
\hline $\begin{array}{l}\text { Fungal } \\
\text { isolate } \\
\text { name }\end{array}$ & Isolate identification & $\begin{array}{l}\text { Sequence identity } \\
\% \text { to closest } \\
\text { match } \\
\text { (Accession } \\
\text { number of closest } \\
\text { match) }\end{array}$ & $\begin{array}{l}\text { Strength of } \\
\text { growth on PDA } \\
\text { plates }^{\text {a }}\end{array}$ \\
\hline
\end{tabular}

Control (soil without added biomass)

\begin{tabular}{llll}
\hline C. S1 & Arthrographis kalrae & $98 \%($ HG004577.1) & +++ \\
\hline C. S4 & Aspergillus sp. & $99 \%($ HQ631021.1) & ++ \\
\hline C. S5 & Arthrographis kalrae & $99 \%($ AB506810.1) & + \\
\hline
\end{tabular}

Jaagichlorella luteoviridis biomass

\begin{tabular}{llll}
\hline J.L S1 & Fusarium solani & $99 \%($ KP265368.1) & +++ \\
\hline J.L S2 & Actinomucor elegans & $99 \%($ AY492091.1) & ++ \\
\hline J.L S3 & Doratomyces nanus & $99 \%($ FJ914668.1) & + \\
\hline J.L S5 & Aphanoascus verrucosus & $99 \%($ KP147971.1) & + \\
\hline
\end{tabular}

Hindakia tetrachotoma biomass

\begin{tabular}{llll}
\hline H.T S1 & Fusarium solani & $99 \%(\mathrm{KM} 268688.1)$ & +++ \\
\hline H.T S2 & Circinella chinensis & $99 \%(\mathrm{JN205855.1)}$ & ++ \\
\hline H.T S3 & Actinomucor elegans & $99 \%(\mathrm{JQ683221.1})$ & ++ \\
\hline H.T S4 & Aphanoascus verrucosus & $99 \%(\mathrm{KP} 147971.1)$ & + \\
\hline H.T S6 & Fusarium oxysporum & $99 \%(\mathrm{GU} 566301.1)$ & + \\
\hline H.T S7 & Doratomyces sp. & $99 \%(\mathrm{HQ832968.1})$ & + \\
\hline
\end{tabular}

\section{Parachlorella hussii biomass}

\begin{tabular}{|c|c|c|c|}
\hline P.HS1 & Fusarium solani & 99\% (KM268688.1) & +++ \\
\hline P.H S2 & Aphanoascus verrucosus & 99\% (KP147971.1) & ++ \\
\hline P.H S4 & Penicillium citrinum & $99 \%(K P 757562.1)$ & + \\
\hline P.H S5 & Fusarium solani & 99\% (HE974458.1) & + \\
\hline P.H S6 & Fusarium oxysporum & $\begin{array}{r}100 \% \\
(\text { KC201696.1) }\end{array}$ & + \\
\hline P.H S7 & Circinella chinensis & 99\% (JN205855.1) & + \\
\hline
\end{tabular}


630 Table 2 Concentration of released reducing sugars from intact or lipid extracted $C$.

631 vulgaris microalgal biomass after $70 \mathrm{~h}$ of incubation with crude fungal enzyme extracts.

632

\begin{tabular}{lllll}
\hline $\begin{array}{l}\text { Enzyme } \\
\text { extract } \\
\text { fungal } \\
\text { source }\end{array}$ & $\begin{array}{l}\text { Sugar } \\
\text { release } \\
\text { from intact } \\
\text { biomass } \\
\left(\mathbf{m g ~ g}^{-1}\right)\end{array}$ & $\begin{array}{l}\text { Saccharification } \\
\text { efficiency from } \\
\text { intact biomass } \\
(\%)\end{array}$ & $\begin{array}{l}\text { Sugar } \\
\text { release from } \\
\text { lipid- } \\
\text { extracted } \\
\text { biomass } \\
\left(\mathbf{m g ~ g}^{-1}\right)\end{array}$ & $\begin{array}{l}\text { Saccharification } \\
\text { efficiency from } \\
\text { lipid-extracted } \\
\text { biomass } \\
(\%)\end{array}$ \\
\hline A. elegans & $59.33 \pm 4.67$ & 34.2 & $\begin{array}{l}92.03 \pm \\
12.68\end{array}$ & 52.9 \\
\hline D. nanus & $98.67 \pm$ & 56.8 & $131.35 \pm$ & 75.7 \\
\hline & 21.33 & & 5.30 & \\
\hline
\end{tabular}

633

634

635

636 